\title{
Chronic Hepatitis C Prevalence and Physician Awareness in Southeastern Turkey
}

\author{
Türkiye'nin Güneydoğu'sunda Kronik Hepatit C Prevalansı ve Hekim Farkındalığı
}

\author{
(1) Nurettin Tunç
}

University of Health Sciences, Gazi Yaşargil Training and Research Hospital, Clinic of Gasttroenterology, Diyarbakır, Turkey

\begin{abstract}
Objectives: This study aimed to investigate anti-hepatitis C Virus (HCV) positivity and physician-patient awareness in Southeastern Turkey.

Materials and Methods: Age, gender and laboratory data of all patients aged 17 years and above, who referred to University of Health Sciences, Diyarbakır Gazi Yaşargil Training and Research Hospital for any reason between August 2016-April 2018 and underwent anti-HCV testing, were evaluated retrospectively. Dates of anti-HCV positive results and demographic data, such as age and gender of the patients with anti-HCV positivity were retrieved from the hospital's information systems.

Results: In the present study, 120.091 cases were tested for anti$\mathrm{HCV}$ and a total of $855(0.7 \%)$ results were positive, i.e. 553 women $(0.61 \%)$ and 302 men (0.98\%). Anti-HCV was positive in $50(0.04 \%)$ cases under 20 years of age, in $361(0.48 \%)$ cases aged $21-40$ years, $237(1.17 \%)$ cases aged 41-60 years, and $207(1.57 \%)$ cases above 61 years of age $(p=0.000)$. The mean delay in diagnosis from the time of anti-HCV identification was 74.88 weeks.

Conclusion: Anti-HCV positivity in our region was found to be consistent with that of regions with low prevalence in Turkey and worldwide. Campaigns to improve awareness among patients and physicians are warranted to prevent delays in HCV diagnosis.

Keywords: Chronic hepatitis C, prevalence, awareness
\end{abstract}

\section{öz}

Amaç: Bu çalışmada amaç, Türkiye'nin Güneydoğu'sunda antihepatit $\mathrm{C}$ virüs $(\mathrm{HCV})$ pozitifliği ve hekim-hasta farkındalığını saptamaktır.

Gereç ve Yöntemler: Sağlık Bilimleri Üniversitesi, Diyarbakır Gazi Yaşargil Eğitim ve Araştırma Hastanesi'ne Ağustos 2016-Nisan 2018 tarihleri arasında herhangi bir nedenle başvurup anti-HCV bakılan 17 yaş ve üzeri tüm hastaların yaş, cinsiyet ve laboratuvar verileri retrospektif olarak incelendi. Anti-HCV pozitif saptandığı tarih ve antiHCV pozitifliği olan hastaların yaş ve cinsiyet gibi demografik veriler hastane bilgi sistemlerinden elde edildi.

Bulgular: Çalışmamızda 120,091 olguda anti HCV bakılmış; 553'ü $(\% 0,61)$ kadın, 302'si $(\% 0,98)$ erkek, toplam 855 'inde $(\% 0,7)$ pozitif saptanmıştı. Anti-HCV 20 yaş altı $50(\% 0,04), 21-40$ yaş arası 361 $(\% 0,48), 41-60$ yaş arası $237(\% 1,17)$ ve 61 yaş üstü $207(\% 1,57)$ olguda pozitifti. Anti-HCV saptanmasından sonra tanıda gecikme ortalama 74,88 hafta idi.

Sonuç: Bölgemiz anti-HCV pozitifliği Türkiye ve Dünya'da düşük prevalanslı bölgelerle uyumlu saptandı. Hepatit $C$ tanısında gecikmeyi önlemek için hasta ve hekimlerin farkındalığını arttıracak programlara intiyaç vardır.

Anahtar Kelimeler: Kronik hepatit C, prevalans, farkındalık

Tunç N. Chronic Hepatitis C Prevalence and Physician Awareness in Southeastern Turkey. Viral Hepat J. 2019;25:101-104.

\section{Introduction}

Chronic hepatitis $\mathrm{C}(\mathrm{HCV})$ is a major global pathogen and the relevant public health problems are expected be increased in the upcoming years $(1,2)$. Even though chronic $\mathrm{HCV}$ is endemic worldwide, its distribution considerably varies by geographic location (3). The highest prevalence rates are reported in Africa and Asia while the regions with low prevalence include the developed countries in North America, Northern and Western Europe, and Australia. Three percentage of world population is chronically infected with chronic $\mathrm{HCV}$, representing an important cause of chronic liver diseases such as cirrhosis, liver fibrosis, hepatocellular 
carcinoma ( $\mathrm{HCC}$ ) and liver failure (4). $\mathrm{HCV}$ is one of the important causes of cirrhosis and HCC. $27 \%$ of cirrhosis cases and $25 \%$ of HCCs are associated with HCV around the world (5). The role of HCV in the etiology of chronic hepatitis cases in our country has increased in recent years (6). Contribution of HCV to chronic hepatitis cases has increased from $23 \%$ to $38.1 \%$ for the last 10 years (7), and its contribution to cirrhosis has increased from $25.2 \%$ to $45.9 \%$ (8).

In a recent study conducted by World Health Organization (WHO) in Europe, HCV prevalence was estimated $2.4 \%$ for Western and Central Europe, and 2.9\% for Eastern Europe (9).

The rate of anti-HCV positivity has been found to be $0.54 \%$ in donor screenings and $1.15 \%$ in the general population in our country. Based on these data, the provinces with an anti-HCV positivity rate higher than $1 \%$ are Afyon, Düzce, Erzurum, Manisa and Samsun (3). Among the cities with high prevalence in adults, the rate was found to be 1.03-1.75\% in Afyon, 1.2\% in Erzurum, $1.3 \%$ in lzmir and $2.1 \%$ in Tokat $(10,11)$.

This study aimed to investigate anti-HCV positivity and physician-patient awareness in Southeastern Turkey.

\section{Materials and Methods}

Data of all patients aged 17 years and above, who referred to University of Health Sciences, Diyarbakır Gazi Yaşargil Training and Research Hospital for any reason between August 2016-April 2018 and underwent anti-HCV testing, were evaluated retrospectively. Dates of anti-HCV positive results and demographic data, such as age and gender of the patients with anti-HCV positivity were retrieved from the hospital's information systems. Anti-HCV positive cases were stratified based on age, i.e. younger than 20 years of age, aged 21-40 years, aged 41-60 years and aged 61 years and above. The duration (weeks) from the date of anti-HCV positive result and the date of HCV-RNA testing (delay in diagnosis) was calculated and classified as a delay of 1-12 weeks (three months), 12-52 weeks (3-12 months) or more than 52 weeks (longer than 12 months).

Patients with missing data were not included in the study.

\section{Statistical Analysis}

Statistical analysis of all data was performed using the SPSS 21.00 package program. Results are presented as percentage for categorical variables and mean \pm standard deviation or median [minimum (min)-maximum (max)] for continuous variables. Chisquare and Fisher's exact test were utilized for the comparison of group rates.

\section{Results}

In the present study, 120.091 cases were tested for anti-HCV and a total of $855(0.7 \%)$ results were positive, i.e. 553/89452 women $(0.61 \%)$ and $302 / 30639$ men $(0.98 \%)(p=0.000)$. Mean age was 44.48 years for anti-HCV-positive cases (min-max: 17-93). Of 855 cases with anti-HCV positivity, only 248 (29\%) were tested for HCV-RNA and received a diagnosis (rate of diagnosis). Among those tested for HCV-RNA, 42/248 (16.9\%) were positive and the rate of HCV-RNA positivity in the general population was found to be $0.03 \%$ (Table 1 ).

\begin{tabular}{|c|c|c|}
\hline & $\mathrm{n}(\%)$ & $\mathrm{p}(<0.05)$ \\
\hline Age (mean $\pm \mathrm{SD}$ ) (year) & $44.8 \pm 18.54$ & - \\
\hline Female & $553(0.61)$ & - \\
\hline Male & $302(0.98)$ & - \\
\hline Delay in diagnosis (weeks) & n (\%) & - \\
\hline $1-12$ & $21(50)$ & - \\
\hline $12-52$ & $6(14.3)$ & - \\
\hline$>52$ & $15(35.7)$ & - \\
\hline $21-40$ & $6(14.3 \%)$ & - \\
\hline $41-60$ & $18(42.9 \%)$ & \multirow{2}{*}{$<0.05$} \\
\hline$>60$ & $17(40.5 \%)$ & \\
\hline Anti-HCV (year) & - & 0.000 \\
\hline$<20$ & $50 / 11227(0.04 \%)$ & - \\
\hline $21-40$ & $361 / 745648(0.48 \%)$ & - \\
\hline $41-60$ & $237 / 20209$ (1.17\%) & - \\
\hline$>60$ & $207 / 13152(1.57 \%)$ & \\
\hline
\end{tabular}


Anti-HCV was positive in $50(0.04 \%)$ cases under 20 years of age, in $361(0.48 \%)$ cases aged 21-40 years, $237(1.17 \%)$ cases aged $41-60$ years, and 207 (1.57\%) cases above 61 years of age. Increased age was associated with increasing rates of anti-HCV positivity $(p=0.000)$. Of those with anti-HCV positivity, $51.9 \%$ were over 40 years of age (Table 1).

Mean age was 56.1 years among the 42 cases with HCV-RNA positivity (min-max: 18-87), with 21 males and 21 females. HCVRNA was positive in 1 patient (2.4\%) under the age of 20 years, 6 patients (14.3\%) aged 21-40 years, 18 patients (42.9\%) aged 41-60 years and 17 patients $(40.5 \%)$ aged 61 years or above, and HCVRNA positivity was more common (83.4\%) in those older than 40 years of age $(p<0.05)$ (Table 1$)$.

Mean duration from a positive anti-HCV result to the HCVRNA testing request (delay in diagnosis) was 74.88 weeks (minmax: 1-308). Three months of delay in diagnosis was noted in 21 patients $(50 \%)$ while the delay was 3-12 months in 6 patients (14.3\%) and more than 12 months in 15 patients (35.7\%) (Table 1).

\section{Discussion}

Based on recent estimates by $\mathrm{WHO}, 185$ million people are chronically infected with HCV worldwide. Most people infected with $\mathrm{HCV}$ are unaware of their infection and most of diagnosed ones cannot still access the treatment (12).

Anti-HCV positivity may indicate a previous and resolved infection, a persistent infection or HCV infection. Anti-HCV may disappear at the end of 10 years in those with resolved acute hepatitis $\mathrm{C}$; therefore, HCV may be considered as an infection which is more common than identified (5).

Prevalence of HCV infection varies around the world. Global prevalence of $\mathrm{HCV}$ infection is estimated to be approximately 2.2-3\% (13). Stratification of regions based on the incidence of HCV infection is as follows: Egypt and Central Africa (10-20\%) (14), Pakistan (8.4\%) (15), Central and South Asia, and North Africa/Middle East (12) are the regions/countries with the highest prevalence, while Northern Europe countries such as Germany $(0.6 \%)(16)$, France $(1.1 \%)(17)$, Austria $(1.8 \%)(18,19)$ are countries with the lowest incidence. HCV prevalence has been reported as $3.2 \%$ in China (20) and $0.9 \%$ in India (21). HCV incidence is $1-2.4 \%$ in our country. Studies conducted in our country report that the rate of anti-HCV positivity ranges from $0.05 \%$ (blood donors) to $51.6 \%$ (hemodialysis patients) across different groups (22). In a study on blood donors in Turkey, anti-HCV positivity was observed at a rate of $2.6 \%$ in Şanlıurfa, $2.1 \%$ in Tokat (11), $0.4 \%$ in Istanbul (23), $1 \%$ in Hakkari (24) and $0.62 \%$ in Siirt (25) while anti-HCV positivity was observed in $0.7 \%$ of the cases in the present study. This rate was consistent with data from Turkey and from regions with low prevalence.

Gregory et al. (26). Showed a significantly higher prevalence of anti-HCV among men compared to women (2.1\% vs $1.1 \%$ ). Consistent with the literature, our study revealed a significantly higher rate of anti-HCV in males compared to females $(0.61 \%$ in women and $0.98 \%$ in men; $p=0.000$ ).

In the present study, mean age was $44.48 \pm 18.54$ years for anti-HCV-positive cases (min-max: 17-93), similar to the mean age $(44 \pm 9.51$ years) reported by Afridi et al. (27).

In a study, anti-HCV prevalence was as follows: $1.0 \%$ for $20-29$ years, $4.3 \%$ for $40-49$ years, $1.6 \%$ for $50-59$ years, and $0.9 \%$ for 60 years of age and above (26). Another study reported similar findings with higher HCV prevalence in those aged $40-49$ years (28) while the lowest rate of $\mathrm{HCV}$ infection was observed in those above 60 and under 19 years of age. A study in Tokat region of our country showed an increasing age-specific prevalence starting from 40 years of age with rates reported as $4.2 \%$ for those aged $50-59$ years, 3.4\% for those aged 60-69 years, and 7.1\% for those aged 70-79 years, which is the highest (11). In the present study, $51.9 \%$ of the cases were above 40 years of age; however, higher rates of anti-HCV positivity were observed with increasing age, compatible with literature (Table 1) $(p=0.000)$. We believe that it is associated with insufficient awareness among patients and physicians in our population.

In a study which tested HCV-RNA in blood samples of antiHCV-positive participants, positivity was more common in men compared to women (89.0\% vs $63.4 \%$ ) (26). A higher rate of positivity was noted in those aged 40 years and above (89.6\%) compared to individuals younger than 40 years of age (60.2\%) (26). Differing from the literature, our study revealed an equal gender distribution of HCV-RNA positivity (21 females, 21 males). HCVRNA positivity was found to be more common (83.4\% in total) in those older than 40 years of age $(p<0.05)$ and this finding was consistent with the literature. The asymptomatic nature of $\mathrm{HCV}$ and insufficient awareness lead to delays in diagnosis and treatment.

Timely diagnosis of HCV is of critical importance to implement strategies that aim to reduce the healthcare burden in the future (2). Low rates of diagnosis constitute the main barrier in this regard (2). A trend to higher diagnosis rates is noted in countries such as Austria, Denmark, France, Germany, Sweden and Switzerland (2). Rates of diagnosis vary across Europe from $31 \%$ in Czech Republic to $81 \%$ in Sweden (2). In the present study, the rate of diagnosis was $29 \%$, which is consistent with regions of low diagnosis rates. On the other hand, the mean duration from anti-HCV positivity to diagnosis was 74.88 weeks (approximately 1.5 years), representing a delay of 1.5 years in diagnosis; delay was three months in $50 \%$, 3-6 months in 15\% and more than one year in 35\% of the patients. The main focus of a national prevention program is to recommend routine screening tests for those likely to be infected with $\mathrm{HCV}$ (29). The low rates of diagnosis in our region reflect the inadequacy of screening strategies and underline the need to revise relevant methods. We believe this issue may be resolved by raising awareness at community level and by informing physicians through an alerting computer program for anti-HCV-positive cases.

\section{Conclusion}

Anti-HCV prevalence in our region is consistent with the data from Turkey and other regions with low prevalence. The time from detection of anti-HCV positivity to diagnosis is noted to be too long. This results in delayed diagnosis and complications. Delays in diagnosis should be prevented by raising awareness among patients and through an alerting computer program for physicians concerning anti-HCV-positive cases.

\section{Acknowledgments}

The author are grateful to Professor Mustafa Kemal CELEN, Dicle University Faculty of Medicine, Department of infectious diseases, for their valuable support. 


\section{Ethics}

Ethics Committee Approval: Retrospectively study.

Informed Consent: Retrospectively study.

Peer-review: Externally and internally peer-reviewed.

Conflict of Interest: No conflict of interest was declared by the author.

Financial Disclosure: The authors declared that this study received no financial support.

\section{References}

1. Davis GL, Alter MJ, El-Serag H, Poynard T, Jennings LW. Aging of hepatitis $\mathrm{C}$ virus (HCV) infectedpersons in the United States: a multiple cohort model of HCVprevalence anddisease progression. Gastroenterology. 2010;138:513-521.

2. Razavi H, Waked I, Sarrazin C, Myers RP, Idilman R, Calinas F, Vogel W, Mendes Correa MC, Hézode C, Lázaro P, Akarca U, Aleman S, Balık I, Berg T, Bihl F, Bilodeau M, Blasco AJ, Brandão Mello CE, Bruggmann $P$, Buti $M$, Calleja JL, Cheinquer $H$, Christensen PB, Clausen M, Coelho HSM, Cramp ME, Dore GJ, Doss W, Duberg AS, El-Sayed MH, Ergör G, Esmat G, Falcone K, Félix J, Ferraz MLG, Ferreira PR, Frankova S, García-Samaniego J, Gerstoft J, Giria JA, Gonçales Jr FL, Gower E, Gschwantler M, Guimarães Pessôa M, Hindman SJ, Hofer H, Husa P, Kåberg M, Kaita KDE, Kautz A, Kaymakoglu S, Krajden M, Krarup H, Laleman W, Lavanchy D, Marinho RT, Marotta P, Mauss S, Moreno C, Murphy K, Negro F, Nemecek V, Örmeci N, Øvrehus ALH, Parkes J, Pasini K, Peltekian KM, Ramji A, Reis N, Roberts SK, Rosenberg WM, Roudot-Thoraval F, Ryder SD, Sarmento-Castro R, SBemela D, Sherman M, Shiha GE, Sievert W, Sperl J, Stärke P, Stauber RE, Thompson AJ, Urbanek P, Van Damme P, van Thiel I, Van Vlierberghe $\mathrm{H}$, Vandijck D, Wedemeyer $\mathrm{H}$, Weis N, Wiegand J, Yosry A, Zekry A, Cornberg M, Müllhaupt B, Estes C. The present and future disease burden ofhepatitis $C$ virus with today's treatment paradigm. Journal of Viral Hepatitis. 2014;21:34-59.

3. Shepard CW, Finelli L, Alter MJ. Global epidemiology of hepatitis C virüs infection. Lancet Infect Dis. 2005;5:558-567.

4. Akbar H, Idrees M, Manzoor S, ur Rehman I, Butt S, Yousaf MZ, Rafique S, Awan Z, Khubaib M, Akram M, Aftab M. Hepatitis C virus infection: a review of the current and future aspects and concerns in Pakistan. J Gen Mol Virol. 2009;1:012-018.

5. Alter MJ. Epidemiology of hepatitis $\mathrm{C}$ virus infection. World $\mathrm{J}$ Gastroenterol. 2007; 13:2436-2441.

6. Barut HŞ, Günal Ö. Dunyada ve Ulkemizde Hepatit C Epidemiyolojisi. Klimik Dergisi. 2009;22:38-43.

7. Okten A. Turkiye'de kronik hepatit, siroz ve hepatoselluler karsinoma etiyolojisi. Güncel Gastroenterol. 2003;7:187-191.

8. Tozun N. "HCV infeksiyonunun Turkiye acısından onemi" Epidemiyoloji ve projeler. In: Cakaloğlu Y, ed. Hepatit C Güncelleme Toplantısı (11-13 Ocak 2008, İstanbul) Konuşma Metinleri. Istanbul: Turk Karaciğer Araştırmaları Derneği, 2008:1-3.

9. Mohd Hanafiah K, Groeger J, Flaxman AD, Wiersma ST. Global epidemiology of hepatitisC virus infection: new estimates of age-specific antibody to HCV seroprevalence. Hepatology. 2013;57:1333-1342.

10. Mıstık R. Turkiye'de viral hepatit epidemiyolojisi - Yayınların irdelenmesi. In: Tabak F, Balık I, Tekeli E, eds. Viral Hepatit 2007. Ankara: Viral Hepatitle Savaşım Derneği, 2007:10-50.

11. Yildirim B, Barut $S$, Bulut $Y$, Yenişehirli G, Özdemir M, Çetin I, Etikan I, Akbaş A, Atiş O, Ozyurt H, Sahin S. Seroprevalence of hepatitis $B$ and $C$ viruses in the province of Tokat in the Black Sea region ofTurkey: A population-based study. Turk J Gastroenterol. 2009;20:27-30.
12. World Health Organization. Guidelines for the Screening, Care and Treatment of Persons with Hepatitis C Infection. April 2014. Geneva: WHO, 2014

13. Lavanchy D. The global burden of hepatitis C. Liver Int. 200929 Suppl 1:74-81.

14. Gower E, Estes C, Blach S, Razavi-Shearer K, Razavi H. Global epidemiology and genotype distribution of the hepatitis $\mathrm{C}$ virus infection. J Hepatol. 2014 61(1 Suppl):S45-S57.

15. Arshad A. and Ashfaq UA. Epidemiology of hepatitis $C$ infection in Pakistan: Current estimate and major risk factors. Crit Rev Eukaryot Gene Expr. 2017.27;63-77.

16. Palitzsch KD, Hottentrager B, Schlottmann K, Frick E, Holstege A, Schölmerich J, Jilg W. Prevalence of antibodies against hepatitis $C$ virus in the adult German population. Eur J Gastroenterol Hepatol. 1999; $11: 1215-1220$

17. Desenclos JC. Epidemiology of hepatitis C. Revue du Praticien. 2000;50:1066-1070.

18. Law MG, Dore GJ, Bath N, Thompson S, Crofts N, Dolan K, Giles W, Gow P, Kaldor J, Lovadey S, Powell E, Spencer J, Wodak A. Modelling hepatitis $C$ virüs incidence, prevalence, and long-term sequelae in Australia, 2001. Int J Epidemiol. 2003;32:717-724.

19. Australian census, 2001, total population. http:// www.abs.gov.au/ ausstats/abs\%40census.nsf/ ddc9b4f9265 7325cca256c3e000bdbaf/7dd97c 937216e32fca256bbe008371f0! OpenDocument\# Census Counts (accessed July 25, 2005).

20. Xia GL, Liu CB, Cao HL, et al. Prevalence of hepatitis $B$ and $C$ virüs infections in the general Chinese population: results from a nationwide cross-sectional seroepidemiologic study of hepatitis A, B, C, D, and E virus infections in China, 1992. International Hepatology Communications 1996.5:62-73.

21. Chowdhury A, Santra A, Chaudhuri S, Dhali GK, Chaudhuri S, Maity SG, Naik TN, Bhattacharya SK, Mazumder DNG. Hepatitis $C$ virüs infection in the general population: a community-based study in West Bengal, India. Hepatology. 2003;37:802-809.

22. Sunbul M, Tabak F, Balık I, Tekeli E (eds). HCV enfeksiyonunun epidemiyolojisi ve korunma. Viral Hepatit 2007. 1. Baskı. Istanbul: Viral Hepatitle Savaşım Derneği, 2007:208-219.

23. Ozsoy MF, Oncul O, Cavuslu S, Erdemoglu A, Emekdas G, Pahsa A. Seroprevalences of hepatitis $B$ and $C$ among health care workers in Turkey. J Viral Hepat. 2003;10:150-156.

24. Tekay F. Hakkari ilinde HBV, HCV ve HIV seroprevalansı. Dicle Tıp Dergisi. 2006;33:170-173.

25. Tunc N, Eraydın H, Cetinkaya E, Oduncu MK, Toy Ş. Siirt Devlet Hastanesi'ne Başvuran Hastalarda HBsAg, Anti-HBs, Anti- HCV ve Anti-HIV Seroprevalansı. Viral Hepatit Dergisi. 2011;17:7-11.

26. Gregory L. Armstrong, Annemarie Wasley, Edgar P. Simard, Geraldine M. McQuillan, Wendi L. Kuhnert, and Miriam J. Alter. The Prevalence of Hepatitis C Virus Infection in the United States, 1999 through 2002. Ann Intern Med. 2006;16:144:705714.

27. Afridi SQ, Zahid MN, Shabbir MZ, Hussain Z, Mukhtar N, Tipu MY, Akhtar F, Yaqub T. Prevalence of HCV genotypes in district Mardan. Virol J. 2013;20:10-90.

28. Wahid B, Waqar M, Rasool N, Rehman Z, Saeed J, Wasim M, Khan ME, Ali A, Rafique S, Sajjad, Idress M. Recent trends in molecular epidemiology of Hepatitis C virus in Mardan, KPK Pakistan. Infect Genet Evol. 2018;66:66-71.

29. Centers for Disease Control and Prevention. Recommendations for prevention and control of hepatitis $\mathrm{C}$ virus (HCV) infection and HCVrelated chronic disease. MMWR Recomm Rep. 1998 16;47(RR-19):1-39. 